\title{
S-Alkylated 1,2,4-Triazoles Derivatives Synthesis, spectral analysis and cytotoxicity evaluation
}

\author{
STEFANIA-FELICIA BARBUCEANU ${ }^{1}$, OCTAVIAN TUDOREL OLARU'², LAURA-ILEANA SOCEA ${ }^{1 *}$, CONSTANTIN DRAGHICI ${ }^{3}$, \\ GABRIEL SARAMET ${ }^{4}$, STELIAN BARAITAREANU ${ }^{5}$, BOGDAN SOCEA ${ }^{6}$, FLORICA BARBUCEANU 7 \\ ${ }^{1}$ Carol Davila University of Medicine and Pharmacy, Faculty of Pharmacy, Organic Chemistry Department, 6 Traian Vuia Str., \\ 020956, Bucharest, Romania \\ ${ }^{2}$ Carol Davila University of Medicine and Pharmacy, Faculty of Pharmacy, Pharmaceutical Botany Department, 6 Traian Vuia Str., \\ 020956, Bucharest, Romania \\ ${ }^{3}$ Military Medical Scientific Research Center, 24-28 Gr. Cobalcescu Str., Bucharest, Romania \\ ${ }^{4}$ Carol Davila University of Medicine and Pharmacy, Faculty of Pharmacy, Pharmaceutical Technology and Biopharmacy Department, \\ 6 Traian Vuia Str., 020956, Bucharest, Romania \\ ${ }^{5}$ University of Agronomical Sciences and Veterinary Medicine of Bucharest, Faculty of Veterinary Medicine, Clinical Sciences \\ Department, 105 Splaiul Independentei, 050097, Bucharest, Romania \\ ${ }^{6}$ Carol Davila University of Medicine and Pharmacy, Faculty of General Medicine, St. Pantelimon Emergency Hospital, 340-342 \\ Soseaua Pantelimon Str., 021623, Bucharest, Romania \\ ${ }^{7}$ Institute for Diagnosis and Animal Health, 63 Dr. Staicovici Str., 050557, Bucharest, Romania
}

This paper presents synthesis, characterization and cytotoxicity assessment of six S-alkylated 1,2,4-triazoles derivatives that were obtained by treatment of some 1,2,4-triazole-3-thiones containing in the molecule phenylsulfonylphenyl and propyl or 4-bromophenylsulfonylphenyl and 4-methoxyphenyl fragments with different alkylation agents (ethyl bromide, ethyl chloroacetate or phenacyl bromide) in basic media. The synthesized compounds were physico-chemically characterized and the IR, ${ }^{1} \mathrm{H}-\mathrm{NMR},{ }^{13} \mathrm{C}-\mathrm{NM} R$ spectra were consistent with the assigned structures. The cytotoxicity of S-alkylated derivatives was evaluated on Daphnia magna crustacean.

Keywords: 1,2,4-triazole-3-thione, alkylation, cytotoxic effect, Daphnia magna

Nowadays it is well known that people are confronted with a very serious problem that is related to infectious diseases and cancer. Therefore, numerous research are currently geared towards discoverynew molecules that to be active on bacteria and fungi resistant to the clinically authorized drugs used at the moment. Also, the discovery of new molecules as anticancer agents with direct cytotoxicity and apoptosis-inducing activity in tumor cell lines is a priority of global research.

Heterocyclic compounds from 1,2,4-triazole class have enjoy of special attention from researchers in the medicinal field, especially because of their biological properties. Moreover, some derivatives from this class have been extensively used in clinic, among Fluconazole, Itraconazole, Voriconazole (used for the fungal infection disease) or Letrozole and Anastrozole (anticancer agents, aromatase inhibitors) [1,2].

Also, 1,2,4-triazole-3-thione/thiole ring systems and their derivatives possess biological properties including antibacterial, antimycobacterial, antifungal, anticancer and antioxidant activity [2-12]. For instance, Hassan G.S. et al. investigated the antimicrobial and antitumoral activity of some 5-(2-aminothiazol-4-yl)-4-substituted-phenyl-4H1,2,4-triazole-3-thiole derivatives, the results indicating that some of these derivatives have biological activity, comparatively with used drugs [3]. Zoumpoulakis P. et al. reported the antimicrobial activity evaluation of a series of 5-[2-(N-dimethylsulfamoyl)-4,5-dimethoxy-benzyl]-4alkyl-s-triazole-3-thiones, most of them having antibacterial and antifungal activities, better than antibiotics used as standards, depending on the alkyl radical linked to the N-4 nitrogen atom from triazole ring [4]. Also, following the evaluation of antitumoral activity of some S-alkylated 1,2,4- triazoles, Hou I.P. et al. reported that the 3-(2,3dihydrobenzo[b][1,4]dioxin-6-yl)-5-(2-fluorobenzylthio)-4phenyl-4H-1,2,4-triazole was the most active against HEPG 2 cancer cell line, comparable to the positive control [5].

Taking into account the importance of 1,2,4-triazole nucleus, many studies are dedicated to synthesis and biological testing of novel derivatives containing this heterocyclic ring with aim to discovery new biological agents with high bioactivity, with low toxicity and with good pharmacokinetic properties.

Our previously research focused on the synthesis, characterization and biological evaluation, including antibacterial, antifungal and antioxidant activity [13-16] of some new compounds from 1,2,4-triazole-3-thiones and S-alkylated-1,2,4-triazole derivatives in order to discover new biological agents.

The aim of the study from the present work was to extended the researcher in these class of S-alkylated-1,2,4triazoles regarding to synthesis, characterization and cytotoxic evaluation of some derivatives.

The biological activity of the synthesized compounds was evaluated using Daphnia magna assay, an alternative method for prescreening of cytotoxicity activity $[17,18]$. Along with other bioassays, this method is widely used for toxicity risk assessment of new compounds, plant extracts, and pharmaceutical substances [19-21].

\section{Experimental part}

Materials and methods

The FT-IR spectra were recorded on a Vertex 70 Bruker spectrometer, using $\mathrm{KBr}$ pellets. The NMR spectra were recorded on a Varian Gemini 300BB spectrometer at 300

*email: laurasocea@gmail.com 
$\mathrm{MHz}$ for ${ }^{1} \mathrm{H}-\mathrm{NMR}$ and at $75 \mathrm{MHz}$ for ${ }^{13} \mathrm{C}-\mathrm{NMR}$ using $\mathrm{CDCl}_{3}$ as solvent. The chemical shifts (ä) are reported in ppm relative to tetramethylsilane (TMS) as internal standard and coupling constants J are in $\mathrm{Hz}$. The elemental analysis determined with a ECS-40-10-Costeh microdosimeter. The melting points were carried out on a Böetius apparatus and are uncorrected.

\section{Synthesis of compounds}

The alkylated derivatives presented in this paper, whose reaction scheme was presented in previous work [22], were prepared starting from 1,2,4-triazole-3-thiones 2a,b known in literature $[23,24]$ that have been synthesized by cyclization of the corresponding acylthiosemicarbazides $\mathbf{l a}, \mathbf{b}$ in a $8 \%$ sodium hydroxide solution.

Thus, by treatment of 1,2,4-triazoles $\mathbf{2 a}$ or $\mathbf{2} \mathbf{b}$ with ethyl bromide, phenacyl bromide or ethyl chloroacetate, in sodium ethoxide media, the alkylated derivatives were obtained: 5-(4-(4-X-phenylsulfonyl) phenyl)-3-(ethylthio)-4(propyl/4-methoxyphenyl)-4H-1,2,4-triazoles 3a,b, 2-(5-(4(4-X-phenylsulfonyl) phenyl)-4-(propyl/4-methoxyphenyl)4H-1,2,4-triazol-3-ylthio)-1-phenyletha-none $4 a, b$ and ethyl 2-(5-(4-(4-X-phenylsulfonyl) phenyl)-4-(propyl/4methoxyphenyl) -4H-1,2,4-triazol-3-ylthio)acetate $5 \mathbf{a}, \mathbf{b}$ by the method described in the our previously papers [13,25] (scheme 1). The derivative 3a was also obtained by treatment of the corresponding 1,2,4-triazole $2 a$ with a solution of $\mathrm{NaOH} 1 \mathrm{~N}$, or a mixture of sodium hydroxide and ethanol, followed of adding of ethyl bromide (see method $B$ and $C$ ).

General procedure for the synthesis of S-alkylated 1,2,4triazoles $3 a, b-5 a, b$ (method $A$ )

To a solution of sodium ethoxide ( $23 \mathrm{mg}$ of sodium dissolved in $10 \mathrm{~mL}$ absolute ethanol) the 1,2,4-triazole-3thione $2 \mathbf{a}, \mathbf{b}(1.0 \mathrm{mmol})$ was added with stirring for $30 \mathrm{~min}$. To the obtained solution the alkylation agent $(1.0 \mathrm{mmol})$ was added and the mixture was stirred for $12 \mathrm{~h}$ at room temperature. The mixture of the reaction was poured into ice water and the precipitate was filtered off, washed with water and the compound was purified by recristalization from ethanol.

\section{Method $B$ (for derivative 3a)}

An equimolar mixture formed by triazole $2 \mathrm{a}$ ( $1.0 \mathrm{mmol})$ and a solution of $\mathrm{NaOH} 1 \mathrm{~N}$ was stirred at room temperature till a solution was obtained. To the solution a stoechiometrical quantity of ethyl bromide $(1.0 \mathrm{mmol})$ was added. The mixture was stirred at room temperature for $12 \mathrm{~h}$ and then was poured into ice water. The obtained precipitate was filtered off, washed with water until $\mathrm{pH}=$ 7 and recristalized from ethanol (yield $=47 \%$ ).

\section{Method C (for derivative 3a)}

To a mixture formed by $1.0 \mathrm{mmol} \mathrm{NaOH}$ and $10 \mathrm{~mL}$ absolute ethanol was added $1.0 \mathrm{mmol}$ of triazole $2 \mathrm{a}$. The mixture was stirred at the room temperature till a solution was obtained. The ethyl bromide $(1.0 \mathrm{mmol})$ was added to the solution and the mixture was stirred for $12 \mathrm{~h}$ at room temperature. The mixture was poured into ice water and the obtained precipitate was filtered off, washed with water until $\mathrm{pH}=7$ and recristalized from ethanol (yield $=69 \%$ ).

3-(Ethylthio)-5-(4-(phenylsulfonyl)phenyl)-4-propyl-4H1,2,4-triazole 3a

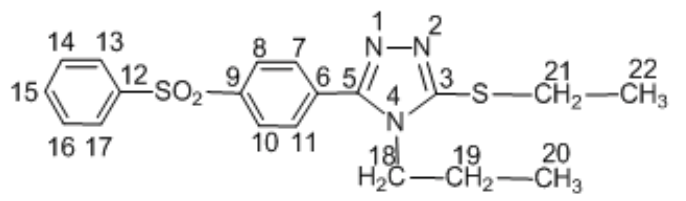

m.p. $=131-133^{\circ} \mathrm{C} ;$ yield $=74 \%(\operatorname{method} \mathrm{A})$;

IR $\left(\mathrm{KBr}, \mathrm{v}, \mathrm{cm}^{-1}\right)$ : 3068w, 2970m, 2933w, 2875w, 1599w, $1570 \mathrm{~m}, 1460 \mathrm{~s}, 1320 \mathrm{~s}, 1160 \mathrm{vs}, 1015 \mathrm{~m}, 850 \mathrm{~m}$;

${ }^{1} \mathrm{H}-\mathrm{NMR}\left(\mathrm{CDCl}_{3,}, \delta \mathrm{ppm}, J \mathrm{~Hz}\right): 8.07(\mathrm{~d}, 2 \mathrm{H}, 8.4, \mathrm{H}-8, \mathrm{H}-$ 10), 7.97 (dd, $\left.2 \mathrm{H}^{3}, 7.5,1.4, \mathrm{H}-13, \mathrm{H}-17\right), 7.76(\mathrm{~d}, 2 \mathrm{H}, 8.4, \mathrm{H}-$ 7, H-11), 7.60 (tt, 1H, 7.5, 1.4, H-15), 7.56 (t, 2H, 7.5, H-14, $\mathrm{H}-16), 3.89$ (t, 2H, 7.7, H-18), 3.33 (q, 2H, 7.3, H-21), 1.69 (sX, 2H, 7.7, H-19), 1.46 (t, 3H, 7.3, H-22), 0.84 (t, 7.7, 3H, $\mathrm{H}-20)$;

${ }^{13} \mathrm{C}-\mathrm{NMR}\left(\mathrm{CDCl}_{3}, \delta \mathrm{ppm}\right): 153.76$ (C-3), 152.68 (C-5), 142.91 (C-9), 140.91 (C-12), 133.54 (C-15), 132.29 (C-6), 129.42 (C-14, C-16), 129.26 (C-7, C-11), 128.24 (C-8, C10), 127.74 (C-13, C-17), 46.27 (C-18), 27.53 (C-21), 23.28 (C-19), 14.91 (C-22), 10.83 (C-20);

Elemental analysis: Anal. Calcd. for $\mathrm{C}_{19} \mathrm{H}_{2} \mathrm{~N}_{3} \mathrm{O}_{3} \mathrm{~S}_{2}$ (387.52 g/mol) : C: 58.89 ; H: 5.46; S: $16.55 ;{ }^{19} \mathrm{~N}: 10.84 \%$. Found: C: 58.94; H: 5.39; S: 16.52; N: 10.78\%;

5-(4-(4-Bromophenylsulfonyl)phenyl)-3-(ethylthio)-4-(4methoxyphenyl)-4H-1,2,4-triazole $3 \mathrm{~b}$<smiles>CCSc1nnc(-c2ccc(OS(=O)(=O)c3ccc(Br)cc3)cc2)n1-c1ccc(OC)cc1</smiles>

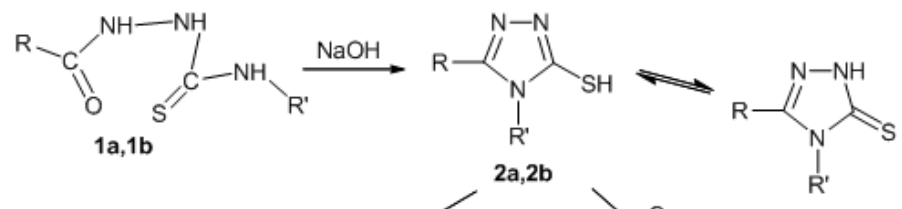

Scheme 1. Synthesis of the compounds $\mathbf{3 a}, \mathbf{b}-\mathbf{5 a}, \mathbf{b}$

$\mathrm{R}$ :

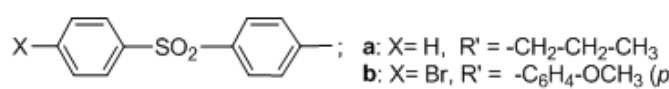


m.p. $=180-182^{\circ} \mathrm{C}$; yield $=68 \%$;

IR $\left(\mathrm{KBr}, \mathrm{v}, \mathrm{Cm}^{-1}\right)$ : 3084w, 3014w, 2964w, 2933w, 2841w, $1604 \mathrm{w}, 1572 \mathrm{w}, 1513 \mathrm{vs}, 1326 \mathrm{~s}, 1253 \mathrm{~s}, 1160 \mathrm{vs}, 1069 \mathrm{~m}$, $1010 \mathrm{~m}, 839 \mathrm{~m}, 571 \mathrm{~m}$;

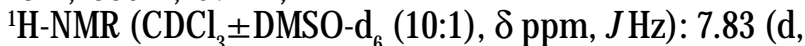
$2 \mathrm{H}, 8.5, \mathrm{H}-8, \mathrm{H}-10), 7.78(\mathrm{~d}, 2 \mathrm{H}, 8.5, \mathrm{H}-13, \mathrm{H}-17), 7.67$ (d, $2 \mathrm{H}, 8.5, \mathrm{H}-14, \mathrm{H}-16), 7.61$ (d, 2H, 8.5, H-7, H-11), 7.16 (d, $2 \mathrm{H}, 8.9, \mathrm{H}-19, \mathrm{H}-23) ; 7.02$ (d, 2H, 8.9, H-20, H-22), 3.88 (s, $\left.3 \mathrm{H}, \mathrm{OCH}_{3}\right), 3.25(\mathrm{q}, 2 \mathrm{H}, 7.4, \mathrm{H}-24), 1.42(\mathrm{t}, 3 \mathrm{H}, 7.4, \mathrm{H}-25)$;

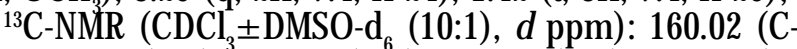
21), 153.98 (C-3), 152.25 (C-5), 141.82 (C-9), 140.92 (C12), 139.33 (C-18), 132.06 (C-14, C-16), 131.03 (C-6), 128.79 (C-13, C-17), 128.58 (C-19, C-23), 127.76 (C-7, C11), 127.06 (C-8, C-10), 125.29 (C-15), 114.72 (C-20, C22), $54.93\left(\mathrm{OCH}_{3}\right), 26.04(\mathrm{C}-24), 14.08(\mathrm{C}-25)$;

Elemental analysis: Anal. Calcd. for $\mathrm{C}_{23} \mathrm{H}_{2} \mathrm{BrN}_{3} \mathrm{O}_{2} \mathrm{~S}_{2}$ (530.46 g/mol): C:52.08; H:3.80; S:12.09\%. Found: C:51.99; $\mathrm{H}: 3.75 ; \mathrm{S}: 12.15 \%$;

1-Phenyl-2-(5-(4-(phenylsulfonyl)phenyl)-4-propyl-4H1,2,4-triazol-3-ylthio)ethanone 4a

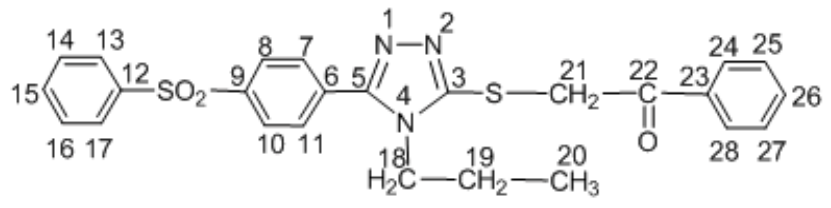

m.p. $=170-172{ }^{\circ} \mathrm{C}$; yield $=84 \%$;

IR $\left(\mathrm{KBr}, v, \mathrm{~cm}^{-1}\right): 3061 \mathrm{w}, 3030 \mathrm{w}, 2969 \mathrm{w}, 2933 \mathrm{~s}, 2875 \mathrm{w}$, $1692 \mathrm{~s}, 1597 \mathrm{w}, 1470 \mathrm{~m}, 1447 \mathrm{~m}, 1316 \mathrm{~s}, 1160 \mathrm{vs}, 1014 \mathrm{~m}$, $839 w$;

${ }^{1} \mathrm{H}-\mathrm{NMR}\left(\mathrm{CDCl}_{3^{\prime}} \delta \mathrm{ppm}, J \mathrm{~Hz}\right): 8.07(\mathrm{~d}, 2 \mathrm{H}, 8.4, \mathrm{H}-8, \mathrm{H}-$ 10), 8.03 (bd, 2H, 7.3, H-24, H-28), 7.97 (bd, 2H, 7.0, H-13, $\mathrm{H}-17), 7.75(\mathrm{~d}, 2 \mathrm{H}, 8.4, \mathrm{H}-7, \mathrm{H}-11), 7.40-7.60(\mathrm{~m}, 6 \mathrm{H}, \mathrm{H}-14$, $\mathrm{H}-15, \mathrm{H}-16, \mathrm{H}-25, \mathrm{H}-26, \mathrm{H}-27$ ), 5.00 (s, 2H, H-21), 3.95 (t, $2 \mathrm{H}, 7.8, \mathrm{H}-18), 1.73$ (sx, 2H, 7.8, H-19), 0.86 (t, 3H, 7.8, H20);

${ }^{13} \mathrm{C}-\mathrm{NMR}\left(\mathrm{CDCl}_{3,}\right.$ d ppm): 194.03 (C-22), 155.14 (C-3), 152.98 (C-5), 144.17 (C-9), 141.99 (C-12), 136.21 (C-23), 135.09 (C-26), 133.10 (C-15), 130.55 (C-6), 130.51 (C-24, C-28), 130.39 (C-25, C-27), 129.92 (C-14, C-16), 129.57 (C7, C-11), 129.35 (C-8, C-10), 128.86 (C-13, C-17), 47.59 (C18), 42.91 (C-21), 24.47 (C-19), 11.93 (C-20);

Elemental analysis: Anal. Calcd. for $\mathrm{C}_{25} \mathrm{H}_{23} \mathrm{~N}_{3} \mathrm{O}_{3} \mathrm{~S}$ (477.60 g/mol): C:62.87; H:4.85; S:13.43; N:8.80\%. Found: C:62.94; H:4.79; S:13.40; N:8.72\%;

2-(5-(4-(4-Bromophenylsulfonyl) phenyl)-4-(4methoxyphenyl)-4H-1,2,4-triazol-3-ylthio)-1-phenylethanone $\mathbf{4 b}$

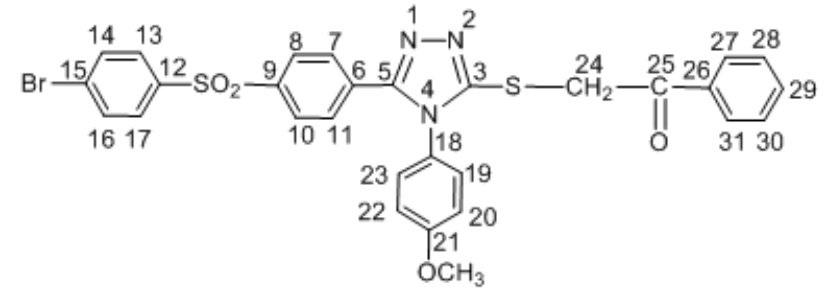

m.p. $=210-211^{\circ} \mathrm{C} ;$ yield $=76 \%$;

$\operatorname{IR}\left(\mathrm{KBr}, \mathrm{v}, \mathrm{Cm}^{-1}\right)$ : 3063w, 3014w, 2960w, 2918w, 2837w, $1680 \mathrm{~s}, 1599 \mathrm{~m}, 1573 \mathrm{~m}, 1513 \mathrm{vs}, 1322 \mathrm{~s}, 1255 \mathrm{vs}, 1159 \mathrm{vs}$, $1069 \mathrm{~s}, 1008 \mathrm{~m}, 840 \mathrm{~s}, 575 \mathrm{~m}$;

${ }^{1} \mathrm{H}-\mathrm{NMR}(\mathrm{CDCl}, \delta \mathrm{ppm}, / \mathrm{Hz}): 8.03(\mathrm{dd}, 2 \mathrm{H}, 7.7,1.5, \mathrm{H}-$ 27, H-31), $7.82(\mathrm{~d}, 2 \mathrm{H}, 8.6, \mathrm{H}-8, \mathrm{H}-10) ; 7.76$ (d, 2H, 8.7, H$13, \mathrm{H}-17), 7.63$ (d, 2H, 8.7, H-14, H-16), 7.61 (bt, $1 \mathrm{H}, 7.7, \mathrm{H}-$ 29), $7.60(\mathrm{~d}, 2 \mathrm{H}, 8.6, \mathrm{H}-7, \mathrm{H}-11), 7.49(\mathrm{t}, 2 \mathrm{H}, 7.7, \mathrm{H}-28, \mathrm{H}-$ 30), 7.18 (d, 2H, 8.7, H-19, H-23), 7.01 (d, 2H, 8.7, H-20, H22), $4.98(\mathrm{~s}, 2 \mathrm{H}, \mathrm{H}-24), 3.89\left(\mathrm{~s}, 3 \mathrm{H}, \mathrm{OCH}_{3}\right)$;
${ }^{13} \mathrm{C}-\mathrm{NMR}\left(\mathrm{CDCl}_{3}, \delta \mathrm{ppm}\right): 192.83$ (C-25), 160.86 (C-21), 154.11 (C-3), 153.20 (C-5), 141.80 (C-9), 139.97 (C-12, C18), 135.11 (C-26), 133.94 (C-29), 132.65 (C-14, C-16), 131.39 (C-6), 129.21 (C-13, C-17), 128.80 (C-28,C-30), 128.47 (C-27,C-31), 128.40 (C-7, C-11), 128.32 (C-19, C23), 127.78 (C-8, C-10), 125.68 (C-15), 115.51 (C-20, C22), $41.15(\mathrm{C}-24), 55.56\left(\mathrm{OCH}_{3}\right)$;

Elemental analysis: Anal. ${ }^{3}$ Calcd. for $\mathrm{C}_{29} \mathrm{H}_{22} \mathrm{BrN}_{3} \mathrm{O}_{4} \mathrm{~S}_{2}$ (620.54 g/mol): C:56.13; H:3.57; S:10.33\%. Found: C:56.17; H:3.51; S:10.29\%;

Ethyl 2-(5-(4-(phenylsulfonyl)phenyl)-4-propyl-4H-1,2,4triazol-3-ylthio)acetate 5 a

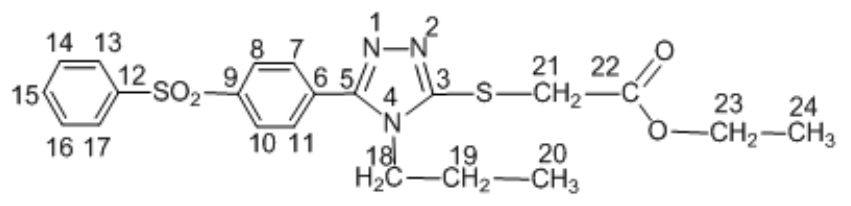

m.p. $=88-90^{\circ} \mathrm{C}$; yield $=72 \%$;

IR $\left(\mathrm{KBr}, \mathrm{v}, \mathrm{cm}^{-1}\right)$ : 3068w, 2971w, 2933w, 2875w, 1745vs, $1599 \mathrm{w}, 1470 \mathrm{~m}, 1452 \mathrm{~s}, 1306 \mathrm{vs}, 1157 \mathrm{vs}, 1028 \mathrm{~m}, 849 \mathrm{w}$;

${ }^{1} \mathrm{H}-\mathrm{NMR}\left(\mathrm{CDCl}_{3,} \delta \mathrm{ppm}, J \mathrm{~Hz}\right): 8.07(\mathrm{~d}, 2 \mathrm{H}, 8.5, \mathrm{H}-8, \mathrm{H}-$ 10), 7.96 (dd, $2 \mathrm{H}, 7.1,1.6, \mathrm{H}-13, \mathrm{H}-17), 7.76$ (d, 2H, 8.5, H7, H-11), 7.61 (tt, 1H, 7.1, 1.6, H-15), 7.54 (t, 2H, 7.1, H-14, $\mathrm{H}-16), 4.21(\mathrm{q}, 2 \mathrm{H}, 7.2, \mathrm{H}-23), 4.15(\mathrm{~s}, 2 \mathrm{H}, \mathrm{H}-21), 3.95(\mathrm{t}$, $2 \mathrm{H}, 7.7, \mathrm{H}-18), 1.71$ (sX, 2H, 7.7, H-19), 1.27 (t, 3H, 7.2, H24), 0.86 (t, 3H, 7.7, H-20);

${ }^{13} \mathrm{C}-N M R(C D C l, \delta \mathrm{ppm}): 168.15$ (C-22), 154.08 (C-3), 151.29 (C-5), 143.05 (C-9), 140.86 (C-12), 133.56 (C-15), 132.02 (C-6), 129.42 (C-14, C-16), 129.28 (C-7, C-11), 128.25 (C-8, C-10), 127.74 (C-13, C-17), 62.10 (C-23), 46.47 (C-18), 35.22 (C-21), 23.43 (C-19), 14.04 (C-24), 10.83 (C20);

Elemental analysis: Anal. Calcd. for $\mathrm{C}_{21} \mathrm{H}_{23} \mathrm{~N}_{3} \mathrm{O}_{4} \mathrm{~S}_{2}$ (445.56 g/mol): C:56.61; H:5.20; S:14.39; N:9.43\%. Found: C:56.69; H:5.14; S:14.35; N:9.52\%;

Ethyl 2-(5-(4-(4-bromophenylsulfonyl) phenyl)-4-(4methoxyphenyl)-4H-1,2,4-triazol-3-ylthio)aceta-te $\mathbf{5 b}$

$$
\text { (1) }
$$

m.p. $=201-203{ }^{\circ} \mathrm{C}$; yield $=77 \%$;

IR ( $\left.\mathrm{KBr}, \mathrm{v}, \mathrm{cm}^{-1}\right)$ : 3082w, 2980w, 2933w, 2841w, 1734s, $1604 \mathrm{w}, 1573 \mathrm{~m}, 1513 \mathrm{vs}, 1324 \mathrm{~s}, 1255 \mathrm{vs}, 1160 \mathrm{vs}, 1070 \mathrm{~m}$, $1029 \mathrm{~m}, 840 \mathrm{~m}, 577 \mathrm{~m}$;

${ }^{1} \mathrm{H}-\mathrm{NMR}\left(\mathrm{CDCl}_{3}, \delta \mathrm{ppm}, J \mathrm{~Hz}\right): 7.83$ (d, 2H, 8.7, H-8, H10); 7.77 (d, 2H, 8.6, H-13, H-17), 7.64 (d, 2H, 8.6, H-14, H16), 7.60 (d, 2H, 8.7, H-7, H-11), 7.18 (d, 2H, 9.1, H-19, H23); 7.01 (d, 2H, 9.1, H-20, H-22); 4.22 (q, 2H, 7.1, H-26), $4.11(\mathrm{~s}, 2 \mathrm{H}, \mathrm{H}-24), 3.89\left(\mathrm{~s}, 3 \mathrm{H}, \mathrm{OCH}_{3}\right), 1.28(\mathrm{t}, 3 \mathrm{H}, 7.1, \mathrm{H}-$ 27);

${ }^{13} \mathrm{C}-\mathrm{NMR}\left(\mathrm{CDCl}_{3}, \delta \mathrm{ppm}\right): 167.98$ (C-25), 161.14 (C-21), 153.93 (C-3), 153.39 (C-5), 142.18 (C-9), 140.43 (C-12, C18), 132.84 (C-14, C-16), 131.68 (C-6), 129.30 (C-13, C17), 128.95 (C-7, C-11), 127.86 (C-8, C-10), 127.75 (C-19, C-23), 126.06 (C-15), 115.63 (C-20, C-22), 62.01 (C-26), $55.67\left(\mathrm{OCH}_{3}\right), 34.57(\mathrm{C}-24), 14.06(\mathrm{C}-27)$;

Elementâl analysis: Anal. Calcd. for $\mathrm{C}_{25} \mathrm{H}_{2} \mathrm{BrN}_{2} \mathrm{O}_{5} \mathrm{~S}_{2}$ (588.50 g/mol): C:51.02; H:3.77; S:10.90\%. Found: C:51.10; $\mathrm{H}: 3.71 ; \mathrm{S}: 10.86 \%$. 


\section{Daphnia magna assay}

The biological assay was performed in duplicate in PP tissue culture wells (Greiner Bio-One) with 10 organisms at a volume of $4 \mathrm{~mL} /$ sample [26]. The solvent, $1 \%$ DMSO was used as negative control. For each compound were tested 6 concentrations ranging from 0.5 to $50 \mathrm{ig} / \mathrm{mL}$. The observations were made at 24 and $48 \mathrm{~h}$, and lethality values (L\%) were calculated. The lethality curves were plotted using the logarithm of concentrations and against L $\% .50 \%$ lethal concentrations (LC50) and 95\% confidence intervals (Cl95\%) were calculated by interpolation on lethality curves. The $48 \mathrm{~h} \mathrm{LC} 50$ was also predicted using Lazar and GUSAR software applications and compared with the value experimentally determined $[27,28]$.

\section{Results and discussions}

In the IR spectra of alkylated compounds, the dissapearance of the stretching band of the NH group from 1,2,4-triazole-3-thiones (3439 $\mathrm{cm}^{-1}$ for $2 a$ and $3433 \mathrm{~cm}^{-1}$ for $\mathbf{2 b}$ ) is a proof that the alkylation of the triazoles with alkylation agents (ethyl bromide, phenacyl bromide or ethyl chloroacetate) took place. Also, the $\mathrm{C}=\mathrm{S}$ stretching band from 1,2,4-triazole-3-thione $2 \mathrm{a}\left(1256 \mathrm{~cm}^{-1)}\right.$ dissapeared in the IR spectra of compounds 3a-5a, indicating the alkylation at sulfur atom. In the case of IR spectra of compounds $3 \mathbf{b}-5 \mathbf{b}$ containing the methoxy group, the band of high intenstity from 1253-1255 $\mathrm{cm}^{-1}$ appeared due to antisimetric stretching vibration $v_{c}$

In the IR spectra of compounds $4 \mathbf{4}$ and $\mathbf{4 b}$ obtained by reaction of triazoles $\mathbf{2} \mathbf{a}, \mathbf{b}$ with phenacyl bromide, the $v C=0$ appeared in the region $1692 \mathrm{~cm}^{-1}$ (for 4a) and $1680 \mathrm{~cm}^{-1}$ (for $\mathbf{4 b}$ ).

The derivatives obtained by reaction of triazoles with ethyl chloroacetate contain in the IR spectra the absorption band due tov $\mathrm{C}=0$ from $-\mathrm{COO}$ group at $1745 \mathrm{~cm}^{-1}$ (for 5a) and $1734 \mathrm{~cm}^{-1}$ (for $5 \mathbf{b}$ ).

În the ${ }^{1} \mathrm{H}-\mathrm{NMR}$ spectra of S-ethyl triazoles $3 \mathbf{a}, \mathbf{b}$ the signals of ethyl protons appeared as quartetfor methylene protons at $3.33 \mathrm{ppm}$ for $3 \mathrm{a}$ and $3.25 \mathrm{ppm}$ for $3 \mathbf{b}$ and as triplet for methyl protons at $1.46 \mathrm{ppm}$ for $3 \mathrm{a}$ and $1.42 \mathrm{ppm}$ for $\mathbf{3 b}$.
The ethylacetate fragment from compounds $\mathbf{5 a}, \mathbf{b}$ recognized in the ${ }^{1} \mathrm{H}-\mathrm{NMR}$ spectra by the signal of ethyl group: the protons from methyl group as singlet, at $\delta \sim$ $1.28 \mathrm{ppm}$ and the protons from methylene group as quartet at $\sim 4.21 \mathrm{ppm}$, with coupling constant $J=7.2 \mathrm{~Hz}$ for $5 \mathrm{a}$ and $7.1 \mathrm{~Hz}$ for $5 \mathrm{~b}$. The phenacylderivatives $4 \mathrm{a}, \mathrm{b}$ and esters $5 \mathrm{a}, \mathrm{b}$ contain a singlet signal corresponding to methlylene protons that appear at $\delta=4.11-5.00 \mathrm{ppm}$.

The ${ }^{13}$ C-NMR spectra of S-ethyl triazoles contain two new signals from ethyl group at $14.91 \mathrm{ppm}$ for $3 \mathrm{a}$ and 14.08 ppm for $\mathbf{3 b}$ corresponding to carbon from methyl group and at $27.53 \mathrm{ppm} 3 \mathrm{a}$ and $26.04 \mathrm{ppm} \mathbf{3 b}$ from methylene group. The characteristic signal from ${ }^{13} \mathrm{C}$-NMR spectra of compounds $\mathbf{4 a}, \mathbf{b}$ is the signal of $>C=0$ that appears at $194.03 \mathrm{ppm}$ for $\mathbf{4 a}$ and $192.83 \mathrm{ppm}$ for $\mathbf{4 b}$. The presence of the ethyl esters derivatives is indicated in the ${ }^{13} \mathrm{C}$-NMR by the signal corresponding to $>C=0$ from ester group that appears at $168.15 \mathrm{ppm}$ for $\mathbf{5 a}$ and $167.98 \mathrm{ppm}$ for $\mathbf{5 b}$. Also, in these compounds the new signals of ethyl group are presented at $\delta \sim 62 \mathrm{ppm}$ for methylene and at $\sim 14 \mathrm{ppm}$ for methyl carbon. Moreover, the signal methylene carbon linked to sulfur atom appeared at 35,22 ppm for 5 a and at $34.57 \mathrm{ppm}$ for $\mathbf{5 b}$. The same carbon signal appear in the ${ }^{13} \mathrm{C}$-NMR spectra of phenacyderivatives at $42.91 \mathrm{ppm} 4 \mathrm{a}$ and $41.51 \mathrm{ppm} \mathbf{4 b}$.

The carbon signals from 1,2,4-triazole ring appear at 153.76-155.14 ppm for C-3 carbon and at 151.29-153.39 ppm for C-5 carbon. As has been shown in our other research $[13,15,25]$, the carbon $C-3$ from these compounds is more shielded than the $\mathrm{C}=\mathrm{S}$ carbon atom from the same position of the raw materials from triazoles class (167.50 ppm for $\mathbf{2 a}$ and $169.28 \mathrm{ppm}$ for $\mathbf{2 b}$ ), demonstrating that alkylation occurred at the sulfur atom.

Referring to the biological testing, the highest toxicity was induced by compound $\mathbf{3 a}$, followed by $\mathbf{3 b}$ and $\mathbf{4 a}$. Compound $\mathbf{4 b}$ showed cytotoxicity only at $48 \mathrm{~h}$, but lower toxicity than $\mathbf{3 a}, \mathbf{3 b}$ and $\mathbf{4 a}$. Compounds $5 \mathrm{a}$ and $\mathbf{5 b}$ which contain an ethyl acetate group linked to the sulfur atom induced no significant toxic effects against Daphnia magna after $48 \mathrm{~h}$, the highest induced lethality being $30 \%$ (table 1; fir. 1 ).

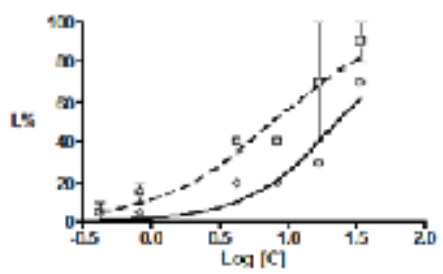

$3 a$

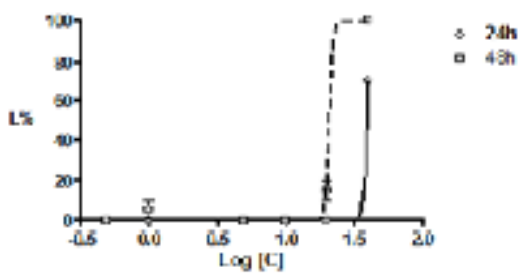

$4 a$

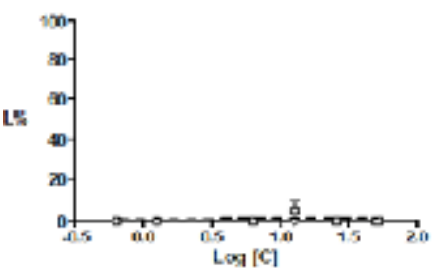

$5 \mathrm{a}$

20k

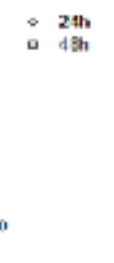

(n)
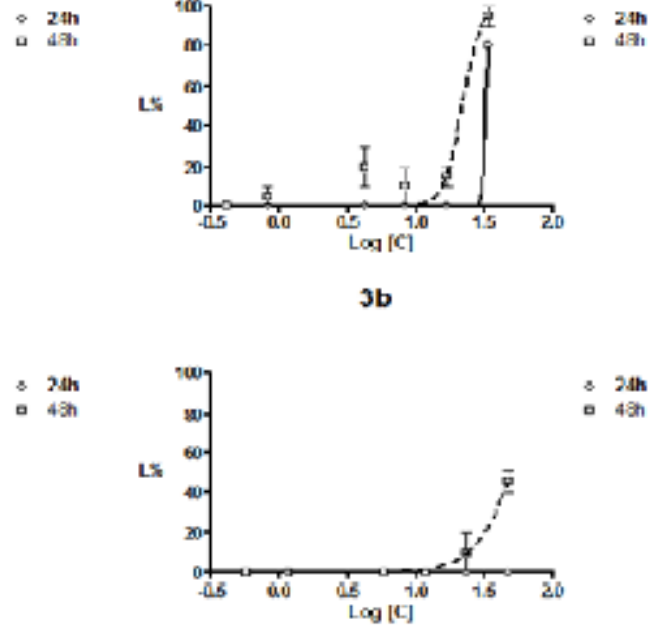

$4 b$

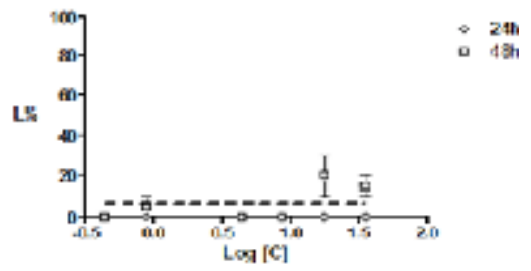

$5 \mathrm{~b}$

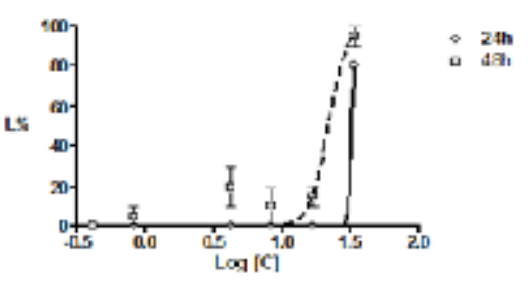

3b

Fig. 1. Lethalithy curves on Daphnia magna at 24 and $48 \mathrm{~h}$ for the tested compounds: $\mathbf{3 a , b}$ $5 a, b$ 


\begin{tabular}{|c|c|c|c|c|c|}
\hline Compound & $\begin{array}{l}\mathrm{LC50}_{24 \mathrm{~h}} \\
(\mu \mathrm{g} / \mathrm{mL})\end{array}$ & $\begin{array}{l}95 \% \text { CI of } \\
\mathrm{LC5} 0_{24 \mathrm{~b}} \\
(\mu \mathrm{g} / \mathrm{mL})\end{array}$ & $\begin{array}{l}\mathrm{LC50}_{45 \mathrm{~h}} \\
(\mu \mathrm{g} / \mathrm{mL})\end{array}$ & $\begin{array}{c}95 \% \mathrm{CI} \text { of } \\
\mathrm{LC5} 0_{45 \mathrm{~h}} \\
(\mu \mathrm{gL})\end{array}$ & $\begin{array}{c}\text { GUSAR } \\
(48 \mathrm{~h}) \\
(\mu \mathrm{g} / \mathrm{mL})\end{array}$ \\
\hline $3 a$ & 22.60 & 13.72 to 37.22 & 7.627 & 4.274 to 13.61 & 0.26 \\
\hline $3 b$ & 32.04 & $\mathrm{NC}$ & 21.60 & 16.57 to 28.14 & 0.01 \\
\hline $4 a$ & $\sim 38.25$ & $\mathrm{NC}$ & $\sim 20.59$ & $\mathrm{NC}$ & 0.05 \\
\hline $4 b$ & $\mathrm{NC}$ & $\mathrm{NC}$ & 49.90 & 44.18 to 56.37 & 0.01 \\
\hline $5 a$ & $\mathrm{NC}$ & $\mathrm{NC}$ & $\mathrm{NC}$ & $\mathrm{NC}$ & 0.14 \\
\hline $5 \mathbf{b}$ & $\mathrm{NC}$ & $\mathrm{NC}$ & $\mathrm{NC}$ & $\mathrm{NC}$ & 0.01 \\
\hline
\end{tabular}

Table 1

RESULTS OF Daphnia magnaBIOASSAY

LC50 - 50\% lethal concentration; $95 \%$ CI - $95 \%$ confidence interval; NC - not calculated due to the obtained results.

The prediction using Lazar application failed to provide information regarding the toxicity of the synthesized compounds due to lack of similar structures. The Lazar software found only one structure related with our Salkylated 1,2,4-triazoles derivatives, this compound being the dibenzothiophene 5,5-dioxide and having a very low similarity threshold of 0.25 . The prediction with GUSAR show ed lower values of $48 \mathrm{~h} \mathrm{LC} 50$ compared to the values obtained in our experiments (table 1).

\section{Conclusions}

The present work describes synthesis, characterization and cytoxicity evaluation of six S-alkylated 1,2,4-triazoles derivatives. The compounds were obtained by alkylation of some 1,2,4-triazole-3-thiones containing arylsulfonylphenyl and n-propyl/4-methoxyphenyl fragments with different alkylation agents. The chemical structure was confirmed by spectral analysis.

The compounds have been tested on Daphnia magna for their cytoxicity assessment. Of the synthesized compounds, $\mathbf{3 a}, \mathbf{4 a}, \mathbf{3} \mathbf{b}$ and $\mathbf{4 b}$ containing an ethyl or phenacyl group in the molecule showed high cytotoxicity to Daphnia magna $(\mathrm{LC} 50<50 \mu \mathrm{g} / \mathrm{mL})$, thereby a high biological activity.

\section{References}

1. ZHANG, H.-Z., DAMU, G.L.V., CAI, G.-X., ZHOU, C.-H., Curr. Org. Chem., 18, no. 3, 2014, p. 359

2. KUCUKGUZEL, S.G., CIKLA-SUZGUN, P., Eur. J. Med. Chem., 97, 2015, p. 830

3. HASSAN, G.S., EL-MESSERY, S.M., AL-OMARY, F.A.M., AL-RASHOOD, S.T., SHABAYEK, M.I., ABULFADL, Y.S., HABIB, E.-S.E., EL-HALLOUTY, S.M., FAYAD, W., MOHAMED, K.M., EL-MENSHAWI, B.S., EL-SUBBAGH, H.I., Eur. J. Med. Chem., 66, 2013, p. 135

4. ZOUMPOULAKIS, P., CAMOUTSIS, CH., PAIRAS, G., SOKOVIC, M., GLAMOCLIJA, J., POTAMITIS, C., PITSAS, A., Bioorg. Med. Chem., 20, 2012, p. 1569

5. HOU, Y.-P., SUN, J., PANG, Z.-H., LV, P.-C., LI, D.-D., YAN, L., ZHANG, H.-J., ZHENG, E. X., ZHAO, J., ZHU, H.-L., Bioorg. Med. Chem., 19, 2011, p. 5948

6. MIOC, M., SOICA, C., BERCEAN, V., AVRAM, S., BALAN PORCARASU, M., CORICOVAC, D., GHIULAI, R., MUNTEAN, D., ANDRICA, F., DEHELEAN, C., SPANDIDOS, D.A., TSATSAKIS, A.M., KURUNCZI, L., Int. J. Oncol., 50, no. 4, 2017, p. 1175

7. HOLLA, B. S., PRASANNA, C.S., POOJ ARY, B., ASHOK, M., RAO, K.S., SHRIDHARA, K., Z. Naturforsch. 61b, 2006, p. 334

8. RADWAN, A.A., ALANAZI, F.K., AL-AGAMY, M.H., Braz. J. Pharm. Sci., 53, no. 1, 2017, p. 1

9. IDREES, M., NASARE, R.D, SIDDIQUI, N.J., Der Chemica Sinica, 7, no. 4,2016, p. 28
10. SHIRINZADEH, H., SUZEN, S., ALTANLAR, N., WESTWELL, A. D., Turk. J. Pharm. Sci., 15, no. 3, 2018, p. 291

11. STEPHEN, P., MADHUSUDAN, N.P., KRISHNA, K.L, ESWAR, M. S, TANUJ, R., PRUDHVI ,S, GURUBASAVARAJ, V.P., Int. J. Pharm. Pharm. Sci., 6, no. 10, p. 185

12. TUMOSIENE I., J ONUSKIENE I., KANTMINIENE K., BERESNEVICIUS Z. J., Monatsh. Chem., 145, 2014, p. 319

13. BARBUCEANU, S.F., ALMAJAN, G.L., SARAMET, I., DRAGHICI, C., SOCOTEANU, R., BARBUCEANU, F., J. Serb.Chem. Soc., 74, no. 10, 2009, p. 1041

14. BARBUCEANU, S.-F., BANCESCU, G., SARAMET, G., RADULESCU, F.S., BARBUCEANU, F., SOCEA, L.-I., BANCESCU, A., Farmacia, 64, no. 2, 2016, p. 237

15. BARBUCEANU, S.-F., ILIES, D.C., SARAMET, G., UIVAROSI, V., DRAGHICl, C., RADULESCU, V., Int. J. Mol. Sci., 15, no 6, 2014, p. 10908 16. BARBUCEANU, S.-F., BANCESCU, G., DRAGHICl, C., BARBUCEANU, F., CRETU, O.D., APOSTOL, T.V., BANCESCU, A., Rev. Chim. (Bucharest), 63, no. 4, 2012, p. 362

17. GUILHERMINO, L., DIAMANTINO, T., SILVA, M.C., SOARES, A. M., Ecotoxicol. Environ. Saf., 46, 2000, p. 357

18. SEREMET, O.C., OLARU, O.T., GUTU, C.M., NITULESCU, G.M., ILIE, M., NEGRES, S., ZBARCEA, C.E., PURDEL, C.N., SPANDIDOS, D.A., TSATSAKIS, A.M., COLEMAN, M.D., MARGINA, D.M., Mol. Med. Rep., 17, no. 6, 2018, p. 7757

19. OLARU, O.T., ANGHEL, A.I., ISTUDOR, V., ANCUCEANU, R.V., DINU, M., Farmacia, 61, no. 5, 2013, p. 991

20. ANUTA, V., NITULESCU, G.M., DINU-PIRVU, C.E., OLARU, O.T., Molecules, 19, no. 10, 2014, p. 16381

21. MARGINA, D., OLARU, O.T., ILIE, M., GRADINARU, D., GUTU, C., VOICU, S., DINISCHIOTU, A., SPANDIDOS, D. A., TSATSAKIS, A. M., Exp. Ther. Med., 10, no.5, 2015, p. 1681

22. BARBUCEANU, S-F., Progrese în chimia 1,2,4-triazol-3/5-tionelor, 2-amino-1,3,4-tiadiazolilor si a 2-amino-1,3,4-oxadiazolilor, Editura Printech, Bucuresti, 2013, p. 38

23. SARAMET, I., ALMAJAN, G.-L., BARBUCEANU, S., DRAGHICI, C., BANCIU, M.D., Rev. Roum. Chim. (Bucharest), 50, no. 1, 2005, p. 19 24. BARBUCEANU, S.-F., ALMAJAN, G. L., SARAMET I., DRAGHICI C., Rev. Chim. (Bucharest), 57, no. 4, 2006, p. 355

25. BARBUCEANU, S.F., SOCEA, L.I., DRAGHICl, C., PAHONTU, E.M., APOSTOL, T.V., BARBUCEANU, F., Rev. Chim. (Bucharest), 68, no. 10, 2017, p. 2436

26. NITULESCU, G., NICORESCU, I.M., OLARU, O.T., UNGURIANU, A., MIHAI, D.P., ZANFIRESCU, A., NITULESCU, G.M., MARGINA, D., Int. J. Mol. SCi., 18, no. 10, 2017, p. 2217

27. MAUNZ, A., GUTLEIN, M., RAUTENBERG, M., VORGRIMMLER, D., GEBELE, D., HELMA, C., Front. Pharmacol., 4, 2013, p. 38

28. LAGUNIN, A.A., ZAKHAROV, A.V., FILIMONOV, D.A., POROIKOV, V.V., SAR QSAR Environ. Res., 18, no. 3-4, 2007, p. 285.

$\overline{\text { Manuscript received: } 21.09 .2018}$ 